\title{
Functional Differentiation and Religious Organizations in Modernity: A Theoretical Analysis Based on Pentecostalism in Brazil
}

\author{
Roberto Dutra ${ }^{1, *}$, João Ricardo Boechat Pires de Almeida Sales ${ }^{2}$ \\ ${ }^{1}$ Laboratory of Management and Public Policies (LGPP), Human Sciences Center, \\ State University of Northern Rio de Janeiro (UENF), Brazil \\ ${ }^{2}$ Federal Fluminense University, Brazil
}

Copyright $\mathrm{C} 2018$ by authors, all rights reserved. Authors agree that this article remains permanently open access under the terms of the Creative Commons Attribution License 4.0 International License

\begin{abstract}
In this paper, we discuss the role of religious organizations based on Niklas Luhmann's theory of functional differentiation. Starting from a reflection on functional differentiation as the defining form of modern society and the relation between religion and other social spheres, we argue that the multiplicity of functional orientations, due to the non-convergence between the perspectives of the different social subsystems, should be the point of departure from empirical analyzes of religious organizations in modernity. We demonstrate the theoretical argument through an analysis of religious organizations that are guided by Pentecostal structures and semantics in the search for the conversion of believers in the Brazilian religious field.
\end{abstract}

Keywords Functional Differentiation, Modernity, Religious Organizations, Pentecostalism

\section{Introduction}

In modernity, the widening of distinction between religion and other social spheres causes a growing incompatibility between expectations and demands of religious and secular behavior, representing a challenge to religions. From the $18^{\text {th }}$ century on - the "theodicy century" [1] -, the theodicy problem has spread out, leading to a moral questioning of divine justice. Religion is confronted with non-Christian metrics and values. Therefore, the theodicy problem should be seen as historically contingent, not as a constant question of all and any religion (as appears to be for Weber). This contingent character, questioning divine justice from a secular perspective (non-religious), may be related to the process of differentiation between religion and society, since it deepens the macrosocial tension between religion and the worldly social spheres (Economy, Politics, Arts, Science etc.)

Not only does this tension affect individual personality in its basic - micro - level, as Weber emphasized, but also in the intermediate level - meso - of religious organizations. Not only do individuals see their own faith confronted with secular demands addressed to their life conduct, but also religious organizations are challenged by structural demands (cognitive and normative) of human nature (Economy, Law, Media, Family, Politics etc.).

However, despite having elaborated an organizational sociology (sociology of bureaucratic organizations), intending to explain the different spheres of value and a typology of organizations and specialists - mainly religious, such as the typology of Sect-Church and the typology of prophet-priest-magician -, he does not approach the tension between religion and the world in a mesosociological level. The relation of religion and other spheres of value (stablishing tension, adaptation, or even, a mutual affirmation) is noticed and approached only in an individual level. According to Weber the tension (as a specific but not only way of relation) between religion and the world may be noticed in a more complex context defined by the imperative of deciding individually for the vocational adhesion to one among several spheres of independent value. In spite of describing the problem related to the difference of a scientist and a politician vocation, as well as the tragic diagnostic of "heartless pleasure" (Fachmenschen ohne Geist) as a whole, not always is he systematical nor explicit, associated to meaning and to the consequences of the differentiation of spheres of value to the individual personality.

The lack of attention to the theme of religious organizations, however, affects the attempt of understanding the meaning and the consequences of 
differentiation of spheres of values to the religious resignification in the society, interpreting - through the references to the transcendent as a source of immanent meaning) the necessity of individuals whose lives are conducted by different spheres of value. If the pre-modern society the stratified moral (with respective conceptions of "good life" of each specific social group) originated and stablished connections between religious and secular demands; in the modern society, the religious organizations play this role. If being born at a certain status group used to interfere in the compatibilization of religious regulation of life and the profane imperatives (military, economic, sexual etc.) addressed to the individual, now being part of or becoming a member of a religious organization defines the relation of faith and life style of worldly social spheres. As a symbolical basis which contributes to a differentiation of religion and other social spheres, faith allows religious organizations - mainly the "communities of faith" (Glaubensgemeinschaften) - to become autonomous to links of status, ethnical and/or family belonging [2]. Nevertheless, the meaning of faith to the mundane life style varies according to the type of religious organization, especially the ones with demands and behavior related to the member's condition.

Considering the group of countries unequivocally classified as part of the occidental modernity, except Europe, it could be said that not only did the search for religions do not decline with modernity, but the religious sphere has each time more modern, playing, in some contexts, important roles in the collective identification of groups and social strata and acquiring degrees of "effervescence" and "devotion" - atypical to the traditional religious belonging, based on the political and territorial anchor much more then on an individual engagement with sacred habits and beliefs [3].

In this paper, we discuss the meaning and role of religious organizations based on Niklas Luhmann's theory of functional differentiation. This paper is structured in three sections. Starting from a reflection on functional differentiation as the defining form of modern society and the relation between religion and other social spheres, it should be to an analysis of religious organizations.

Later, in the second section, we argue that the multiplicity of functional orientations, due to the non-convergence between the perspectives of the different social subsystems, should be the point of departure from empirical analyzes of religious organizations in modernity. The argument is illustrated with a historical formation of religious organizations which will be empirically studied in the development of the Brazilian religious field, highlighting the following aspects: 1) the economic survival of the organization, 2) career structure and 3) the external competition with other institutions.

In the last section, we present a comparative analysis of the "Pentecostal trident" (the theology of prosperity, spiritual war and flexibilization of traditional habits and customs) as systematization structures of religious demands, observed in different religious organizations, stressing the contingent relation of these demands with social demands of different strata.

\section{Functional Differentiation, Secularization and Religion in the Modernity}

The concept of secularization is directly linked to the concept of modernity. It stablishes the kind of relation between religion and society of the modern era. The basic consensus regarding the concept refers to the transaction to modernity: the modern world breaks the religious monopoly of dictating a view of totalizing world, capable of encompassing the whole set of social spheres. However, the meaning and consequences of this rupture to the relation between religion and society in the subsequent of modern society has not been consensual. If, at the dawn of modern age, sociology inherited the illuminist thesis of decline of religion, the evolution of modernity proofed it wrong. Either because the concept of modernity cannot be reduced to the Occident anymore, or because the occident itself does not testify the decline of religion, it is a fact that the development of modernity challenged and keeps on challenging the concept of secularization. The teleologic character - implicit or explicit in the concept of secularization - is a result of premises concerning modernization, which also directly affect the concept of differentiation.

As the theories of modernization and their premises of diffusion and convergence around a similar model of differentiation and social organization based on the parliamentary democracy, the State of right, the liberal economy of market, the rational science and the confinement of religion to the private sphere turned out to be mistaken, the search for a general concept of secularization is likely to be seen as necessarily compromised to the Eurocentric normativism, unable to embrace the diversity of situations related to the theme [4]. Abandoning generalization concepts seems to have become the rule.

The theory of differentiation of spheres, for so long known as the unquestionable nucleus of the thesis of secularization, seems to be very criticized nowadays, specially the variables that affirm a progressive differentiation between spheres and their pacific growth with the convergent telos of social evolution. In attempt of reacting to these critics, the conception of "multiple modernity" [5] starting point to the concept of "multiple secularities", emphasizes the multiple form assumed by differentiation of spheres. The focus is on the different regional and national forms of differentiation and integration between religion and society. The main idea is to break from the stage-by-stage conception which sustain 
the convergence of different contexts, either regional, national or social ones, that express and reframe the functional differentiation, as if at the end the diffusion would be completed, for all regions of the globe, in the same form of organizing the relation between religion and the different autonomous social subsystems.

By leaving any teleologic perspective, the theory of functional differentiation of Luhmann turns out to be capable of bringing a wider comprehension of the modern secular condition that considers different assumed forms of the differentiation between religion and society. Instead of, for example, following the pre-determined path in a growing withdrawal of religion from public space as a requirement to the differentiation between religion and politics, the luhmannian approach does not define if and how religion may be more or less potently expressed in the modern social life; there is no telos, neither in terms of decline, privatization, nor of deinstitutionalization. What may be seen is an evolution due to an inevitable dose of contingency and chance.

Therefore, functional differentiation and secularization, as opposed to be treated as point of arrival (telos) and convergent model to the relation of religion and society, are actually starting point to understanding different forms and tendencies (sometimes controversial) accepted with the development of religion in modern age.

This anti-teleologic perspective brings another great advantage to understanding the modern secular condition: the inductive character of the functional differentiation. In disagreement with Parsons [6], for example, who deductively defines the functional differentiation as the specialization of pre-established societal functions (the four famous functions of the AGIL scheme). Luhmann works on the inductive (and teleologic) that the socially relevant functions are a contingent and historical product of the society evolution itself; the formation of functional systems (through the differentiation process) produces the social functions, not the other way round. Which means the set of functional systems must be conceived as open. To the comprehension of secular condition, possibility to overcome the simplistic dichotomy religion/State is a formula to learn the differentiation of spheres. On the other hand, there are contrasting approaches as Pierucci's [7], which limit the secularization to the differentiation between Church and State, as the luhmannian perspective, which emphasizes that, with the functional differentiation, spheres - such as education, medicine, mass communication, arts etc. - also constitute the secularized world, i.e. the world organized according with autonomous rationalities of religion.

Secularization designates the way the functionally differenced social world may be noticed in the religious perspective. While the concept of religion registers the boundary between the religious and the mundane universe, the concept of secularization characterizes the mundane universe as composed by differentiated logics of the religious perspective of the world.

Regarding the relation of religion and society in Europe, between the $11^{\text {th }}$ and the $18^{\text {th }}$ century, still in a pre-modern stratified and feudal society, it is possible to notice a differentiation of religion as social sphere that will, at once, limit and stimulate the differentiation of other spheres, such as economy, politics, arts and science [8]. The religion - both for Weber and Luhmann - was the first sphere of value (or functional system) to differ from other social spheres. Nevertheless, this differentiation did not lead to the formation of a group of autonomous spheres of value (which would only happen in the transition to modernity, especially after the Reformation). Instead of asserting itself as a sphere of value among others, pre-modern religion stood as a central sphere of all the cosmologic order, covering, through a unitary interpretation of world, and the other social spheres. For that matter, the autonomation of other spheres (such as politics, science, economy, arts and the erotic sphere) will be conquered as an autonomation towards religion, which will remain, in the process of transition to modernity, as "victim" much more than "protagonist" of the differentiation process of the society. The ascetic Protestantism, by radicalizing the tension between religion and the world and trying to rebuild the regulation of the lifestyle in the worldly spheres of value based on religious motivations and rules, shows this condition of religious sphere as "victim" of the social differentiation process. It refers to an effort to reconquer the territory that has been taken by the world. An effort that, by creating a religious sense that sacrifices the moral value of the engagement with professions and secular activities, ends up (as points out Weber with the "consequences paradox" formula) favoring the differentiation process of spheres of value; which was supposed to be avoided.

In Europe, the religious sphere, which has been the first to become autonomous and different from all the others in the social world, will develop symbolical and institutional mechanisms so as to guarantee the religious integration of people's lifestyle in all social aspects, especially those in conflict with the specific rationality of religion: economy, politics, arts and science [9]. This alternative of not radicalizing the tension between religion and the world to the lay people lifestyle, among other factors, will ensure this integration, creating varied forms of adaptation between the religious and worldly demands, which, as demonstrated in the paradigmatic example of indulgences, will allow the constant and uninterrupted neutralization of risks that a mundane lifestyle would bring to the religious destiny (salvation or condemnation) of the individuals. In this context, the radicalization of the religious ethic and the worldly demands is restricting to the lifestyle of a virtuous minority, being the extramundane ascetism its typical expression. The masses, especially the ones from the rural and feudal world, did not experiment a rationalized religion and, therefore, in conflict with the world. This was, in fact, essential to allow the religious integration of life conduct. 
Summing up, this religious integration does not come from the radicalization of the autonomation potential of the religious spheres nor of its counter position to the world, but before the contention of this potential through mechanisms of adaptation between ethic-religious demands and secular spheres.

With the religious Reformation, the opposite happens. The Ascetic Protestantism, mainly, by radicalizing the ethic of world rejection and accenting the tension between immanence and transcendence, ends up contributing to the differentiation between religion and other spheres of value. After failed attempts of conciliating religious confession and politic domination, the Reformation brings an effective separation between these two spheres. The ascetic Protestantism, in turn, besides propitiating the establishment of the ethic of intramundane professional work, favoring the engagement of the individual with the activities and professions originated in the differentiation of social spheres, leads to an individualization of the religious, which obtains the sense of decision and "disritualized" individual conviction. This disritualization process is not the determinant, though. It must live with new ritualities - which allow the religious organizations to structure the individual decision to faith (as the Pentecostalism demonstrates).

In a macro-sociologic level (the most abstract dimension of the social order), the evolutive result is that, from the religious perspective, the society is split in two: the religious and the non-religious side. Thus, the concept of secularization reinforces the attempt of religion to reenter a differentiated social environment, which is not oriented by religious spheres, but their own legalities (Eigengesetzlichkeiten). The biggest mistake concerning the concept of secularization was, possibly, assuming from the differentiation between religion and society in the macro level of the assertive spheres of value the end of religion both from the meso level of religious organizations and groups (and loss of influence, as it was in Europe) and the micro level from daily interactions and individual religiosity.

The relevance of organizations as social system is directly linked to the challenges brought by the functional differentiation and secularization. Despite stating its ethnocentrism, especially its connection with the philosophical-political secularistic program of reducing the Church influence in the society, Luhmann does not defend abandoning the concept of secularization. The key to avoid this ethnocentric understanding is to restore the relation with the meaning of the Latin word saeculum in the occidental tradition: the catholic designation to the sinful and suffering world, in need of salvation. Currently, this original meaning may still be seen, since the most important is the delimitation of a mundane sphere in constant tension with the religion. Secularization is not a privatization process, deinstitutionalization or simple decline of religion [9]. It is the form that religion observes the surrounding social world which is ordered by non-religious criteria, i.e., the form religion designates its other side: "It refers to a description of the other side of societal religious form, the description of its inner societal environment [...] And it refers to a description made by a particular observer, namely, religion; or more exatcty: a description of the societal environment through this, and only, this observer" [10]

Before reinforcing any tendency about religion in the modern world, the concept of secularization issues the religious world conception itself in a societal environment which is not ordered by religious principles. The generalizable nucleus of the secularization concept is that it designates a social world, constituted by different systemical perspectives of observation through a specific perspective: religion. To Luhmann, the concept serves to, firstly, learn the social conditions of faith - the contingence of faith and lifestyles and religious worldviews - which are installed with the deterioration of a stratified society in strata and do the integrating cosmology offered by the religion. Hence, the focus of the secularization concept is in the transition to modernity: the later societal evolution that affects and reconfigures the religion-society. It requires, however, other categories (such as the "multiple secularities") capable of learning the variations resulting from the resignification of the functional differentiation and the secularization.

The pre-modern forms of religion kept structural relations of interdependence both with the stratified differentiation and the central-peripherical one. In the transition to modernity, these structural relations have a new pattern, and religion is not obliged to recruiting its "specialists" from the nobility. With the end of the stratification primacy, religion ceases to be ontologically linked to the hierarchic social order. Besides, the level of semantics, this transition is reaffirmed with the destruction of cosmic correlates of society, ontologically hierarchized (with strata): society is no longer a system that is sustained by the world. The partial systems that emerge with the functional differentiation are no longer described as parts of a world that is unified by a multiple-essence cosmology (Essenzkosmos); they create, on contrary, their own "worlds". While in the pre-modern world, religion monopolistically conceived the world to all the other social systems [11], in the modern society, functionally differenced, the world is fragmented in different systemic perspectives, and religion reacts to this describing the society and the world as secularized. Secularized is, therefore, the representation, elaborated by the religious perspective, of a society that does not fit in the ontological supremacy of religion [12]. This corresponds to saying that the representation religion does of a world in which supremacy and interpretation is not its monopoly. It is noticeable that, although Luhmann the dimension of societal differentiation, neglected by Taylor, both authors converge in defining secularization as a set of conditions of 
religious life in a world that escapes and, frequently, is against religion. It seems, this convergence in the result indicates that both theoretical and methodological paths are much more complementary than dissonant.

Secularization assumes that filiation and engagement level with religion become optional. It is a way of attribution and self-description of the religious act, this consolidates, in the dimension of individual and collective identities, the modern conditions of faith, i.e., the "eminent scenario" (Taylor, 2007), in which believing and practicing a religion is an option. This being said, any and all the social connection of religious nature (including the status of member of a religious organization) becomes a contingent association. The religious life cannot be based on the human nature or any form of collective belonging defined by an essentialist form; now, the last guarantee of religious conviction is individual life [13]. But it is not a unilateral individualization of the religious inclusion. As it also represents the destruction of ontological pillars of faith, this process of individualization is followed by a growing and constant necessity of care and social support. Sharing faith convictions is not related to a "spontaneous" existence that may be assumed through an ontological essence. As individual life journeys go by, the biographic individualization of religious inclusion can only find social support with

"... the visible and limitable construction of communities, in which faith meets social confirmation, even if the others do not share this faith or if they have other beliefs. In the modern society, sharing convictions is an exceptional phenomenon, an outstanding experience, pleasant, and that may lead individuals to join a group which provides the reedition of this experience" [14]

Not even religious phenomena, strongly engaged to a discourse of denial of the secular condition and own functional differentiation, may escape the necessity of building a social support to the religious faith in a society that is not exclusively dictated by religion, i.e., secularized. In dimension of the social practices, the functional differentiation and the secular condition are imposed even to the ones that in the discursive plan were against them:

Fundamentalisms of different types, revivalisms, faith renovation through sacred performances, new mysticisms etc., may be explained by the intensity of the engagement that they produce: conditioned to the secularization, these different movements and religious organizations go against secularization. They are based on modern conditions, which offer the opportunity to some opposition, much more than on their own historical sources, which up-to-date the fundamentalist form [15]

The secular condition does not refer to the convergence of regional paths of development towards the same model of structuring the relation between religion and society, but to the common starting point to the formation of different religious lifestyles. From this starting point emerges a religious modernity marked by a variation of forms of organizing both the religious sphere itself and its relationship with the other spheres. Some of these forms have been particularly vigorous. As it may be seen with the disregard of the evangelical Pentecostalism to the processes of social exclusion which affect the individuals of other functional systems and, somehow, include them in the religious life. To Luhmann, this religious form is most likely to revel the social potency of religion in modern society. Even though it becomes necessary to remember all evolutive change is retrospectively accessible [16], the success of organizational models and forms of internal structuration of religious sphere, as well as the Pentecostalism, in the configuration of a global dynamics of diffusion and imitation (despite variations) shows the organization factor is decisive in the definition of what future religious modernity will be.

Subsequently, we analyze how the centrality of organizations and of functional differentiation to the definition of the secular condition produced a religious globality which structurally affects all types of practice and religious belief that seek to remain alive and relevant in the world.

\section{Modern Religious Organizations: Autonomy of Religious Phenomenon and Multiplicity of Functional Orientations}

To Werron and Heintz [17], since the second part of the $19^{\text {th }}$ century, potentially global comparative communications will allow stabilizing the expectations about communications and relations of competition and cooperation among social units in different functional systems - non-spacial.

Global functional systems are created when their operations and social units, oriented by their value code (mainly organizations) consider as a reference a sense of possibility that transcends all kind of local connection: "According to this logic, all systemic operation protects the whole word as comparison horizon" [18]. The criteria is not the existence of communications external to the local frontiers - which is not exclusive modernity data -, but the emerging of an expansionary logic based on the comparative communication among absent.

The thesis of these sections is the concept of globalization may equally be applied to the functional system of religion. The mechanism that establishes the religious globality is also the formation of a global sphere of references and comparative practices which directly affect different regions, spreading patterns of organizational adaptation to mundane systematic 
rationalities that make the secularization a universal category. The religious sphere is based on structured operations of comparison and observation which integrate the different religions and religious organizations in one single universe in search of believers.

The Christian missionary movements that emerge from the $19^{\text {th }}$ century on were decisive to the construction of this globality of religious sphere. The global history [19] copes with reconstruction relations and mimetic transformation of religions through contact with Christian missions. The relation of antagonism, instead of stops, favors the imitative process and growing integration of global religious sphere [20] However, this was a sporadic event, without any significate structural consequence to the construction of an effective religious globality based on mutual institutionalized observation. As in other functional systems, only in the $19^{\text {th }}$ century the institutionalization of the mutual observation of second order (the observation of the other's observation) leads to the construction of a global religious sphere. Only with the Christian missions in the $19^{\text {th }}$ century this kind of observation has a lasting character, working in a statistical-populational logic and attracting the attention of actors, due to the continuous circulation of believers through different religious organizations [21]. The distinct religious constitute the internal segmental differentiation of the global religious sphere, driven by the search for believers in the global horizon of possibilities of conversion.

The north American Pentecostalism is of special interest since it was the basis for the missionary activity, responsible for the beginning of religious globality. According to Casanova (2008), it refers to the first and pragmatic historical case of a global culture, not territorial or decentralized. As a consequence of the expansion of the North American missionary Pentecostalism, the competition and religious pluralism are projected in the world. Other religions started to be observed as well as self-observed in a competitive perspective as religious of exclusive membership formed by contingent acts and reversible conversion possibilities. Since the $19^{\text {th }}$ century, this perspective of totalizing observation is supported in the conversion act, consequently all this religious mobility is attributed to this fact, including non-Christian religions.

The role of these missionary campaigns in the institutionalization of a global religious sphere may also be identified in the inter-religious convergences caused by the diffusion of models of organizational adaptation of religion in the horizon of possibilities of conversion. Strands of Islamism, Hinduism, Buddhism and even Catholicism built organizations with the purpose of promoting or avoiding conversions. Many organizations, for example, adopted the non-religious sphere of means of mass communication, especially to a calculated use of advertising knowledge in the search of believers.

Most of the latest theses about the relation between modernity and religion do not put much importance to the meso-sociological dimension of religious organizations. In these concepts, the relation between individual and religion is not noticed as a relation mediated by organizations. To Perzke and Tyrell [22], it refers to a Eurocentric approach that represents few European countries, in which religious organizations experimented a growing decline, as the expression of religious modernity. In order to correct this perspective, it would be essential to analyze the global religious field constituted with a internal dynamic of north American missionary denominations as the most faithful expression of religion in modernity.

Unlike in Europe, the deregulation dynamic, competition, denominational pluralism and individualization of north American life would be marked, among other aspects, by the successful combination of organizational rationality and "religious vitality" [23]. Considering religious mobility and missionary work as behavioral expressions typical of an environment of denominational competition for conversion or reconversion of churchgoers, we find an organizational objective of religious nature which favors, at the same time, strategic innovations from all of denominations that compete for religious public. Following mentioned idea, it may be said that the American scenery (similar to the Brazilian one in its more recent configuration) is pragmatic when it comes to handling the tension between religion and world in the meso level of religious organizations, since strategic organizational rationality and religious objectives establish a mutual effort relation, allowing organizational religiosity to be kept and widened even with its emphasis necessary in non-religious criteria (such as media time or even economic sustainability of denominations) of success. This organizational form, due to the successful combination of religious logic and other systemic rationalities and of its affinity with the development of a global religious sphere open to competition, is one of the main (if not the main) representative of religious modernity. Its potential of development in a secularized world society may easily be attested when considering the great success of the Brazilian Pentecostalism in the south hemisphere.

This empiric reality of evolution, vitality and adaptation of religious organization, which allows them to adopt and develop strategic rationalities adequate to the unavoidable non-religious references in a global society - functionally differenced in favor of particularly religious objectives and interests -, does not contradict the global character of differentiation between religious and non-religious. On contrary, the globality of this differentiation itself explains the diffusion of organizational models developed to cope with the unavoidable condition of organizing the religious action in a world which is also structured by autonomous references and logic, such as economy, politics, science, means of mass communication etc.

Analyzing how the Weberian sociology and, posteriorly, the Bourdieusian link the formation and development of religions with different social groups, it is noticeable that 
the relation between religion and social interests is always mediated by religious specialists and organizations. In a modern society, this organizationally mediated relation may be observed as well. As in Brazil more than $90 \%$ of the population self-declares catholic, evangelical or spiritism adherents, different currents of Christianism fit different social classes in homologous and at the same time varied organizational forms.

By developing his sociology of types of religious specialists - mage, prophet and priest -, Weber [24] observes that when a religious professional is successful, this leader attracts disciples. The conquering of new believers is the particularly religious of religious organizations, especially in contexts of pluralism and competition. The global religious modernity has in the Brazilian religious field one of its diffusion centers, and Pentecostalism with its innovations and organizational developments is one of the decisive factors.

The Weberian theme of religious specialists becomes an important element of the sociology of religion, directly analyzing the meso-sociological phenomenon of religious organizations. He states disciples do not follow the specialists for believing their teaching, but also because they find in the specialists' message or exemplar conduct means of satisfaction of their interests and social desires. This demonstrates believing a specialist, in his message and exemplar conduct, means to see in this leader a possibility of satisfaction of their interests and desires.

Nonetheless, both in Weber [25] or Bourdieu [26], the interests developed by religious organizations and specialists are not merely extensions of social interests. As religion becomes gradually more autonomous in terms of social sphere with its own logic, it elaborates religious interests from the raw-material of social interests from different groups, allowing that other distinct social interests to connect with the religious interests. Once organizations and/or religious specialists elaborate common interests which are able to transcend, in a certain way, the bounders of social interest, it will stimulate the adhesion of different social groups to these institutions and specialists in order to achieve these religious interests. Certainly, the adherents of this organization may be from different social classes; however, once they tend to share social interests, individuals of a same class have more affinities with religious organizations that match their own interests. Therefore, the relation between religious organization and social class is not the determinant, but it is a relation of contingent affinity.

Observing how modernity affects and rearranges religion enables us to have a better understanding of how religious organizations influence this process. The pre-modernity is characterized by religious influence in notions of the natural, subjective and social world. Modernity breaks this configuration, deconstructing these three notions of world. When facing this new social reality, the differentiation of society and religion demands new religious strategies in order to reconstruct couplings with society and social interests.

With the end of the religious supremacy over the other social spheres, modernity is marked, as affirms Luhmann [27] by the functional differentiation, since the modern society is formed by distinct spheres which fulfill specialized functions.

Even if every organization privileges a specialized function, these organizations have several other functional orientations. For example, the religious organization has as specialized function intermediate the communication between the divine message and the individual, acting as meeting point between the transcendent and the immanent. However, as this organization has to obey the law and even pay employees, it needs to be oriented by juridical and economic considerations. In this secularized society, marked by the autonomy of social spheres, religion acts as part of these spheres, trying to influence the others through the construction of religious ethics and structural organizational couplings; not becoming the central sphere of interpretation of the world, though. Hence, the relation of religion and society establish a non-hierarchic pattern.

Fulfilling social functions, not only do the successful religious organizations survive, but also convince the other social strata that their services are fair, moral and important, affecting their social environment [28].

Not only does a religious organization influence the survival of religious functions in a secularized society, but also other spheres. The secularization does not necessarily mean the decline of religion in the public sphere; it only shows the religious influence on other spheres is not direct, obeying the logic of each social sphere. In the last decades, for instance, a diversity of works was produced to attest the religious influence in the politic field [29] [30] [31] [32]. These authors observed how the political power of religious organizations goes beyond the capacity of these organizations in electing candidates. The political agenda itself, which favors moral questions, makes religion a political power that cannot be ignored in debates and public controversies. However, the influence of religious organizations in the political sphere requires these organizations to develop structures with political functions. Adapting to political spheres, the religious organizations deepen their multiplicity of functional orientations to the point of promoting the emergence of particularly political organizations such as social parties and movements.

A religious organization is a material (temples) and immaterial (doutrines, theologies) expression to the attempt of religion to be part of a society which no longer is exclusively based on religious values. It is a modern organization, since it is affected by the other social spheres (politics, law, economy, media), fulfilling a religious function specialized in the society; not ignoring the other social function, though. On the one hand, the religious organization is supposed to carry out a specialized function, namely, intermediating the relation between the divine 
message (though the religious specialist) and the individuals. It becomes the exchanging local between the human being (worship, prayer, offerings) or the divine (ethical message, promises, miracles). On the other hand, it enables the interaction between religious function and other functions, e.g. economic and politic.

\section{Religious Organizations and the Modern Religious Field}

The religious modernity in countries similar to Brazil is characterized by the emergency of religious movements which, as the Pentecostalism, are born as a challenge to adapt to a new world which does not submit to the cultural and institutional ordinance of religion. This means religious organizations, to acquire adherence, need to deal with the fact that life conduct of the individuals cannot be completely regulated by religious norms. In Brazil, specially, we may see, at least for the last four hours, the reconfiguration process of the way the national religious field is integrated to the global one, founded in the production and the reproduction of a horizon of possibilities of believers' adherence.

Nevertheless, suffering the consequences of global secularization [33], converting believers and channeling their relation with transcendent is not enough to the religious organization. It has to be aware of opportunities and challenges of a differentiated society, marked by competition of different spheres, including the religious sphere. If competition and search for affirmation of an organization in the religious sphere connects it to religious objectives, it also obliges the organization to consider other variables, some external to religion. We highlight following variables: 1) external competition with other competitions, 2) economic survival of the organization, 3 ) structuring of internal careers.

The first aspect to be considered in these analyzes of religious organization in this paper refers to the competition among religious organizations. This question demonstrates an important influence of modern society on religious organizations, i.e., the religious pluralism, or even, the existence of different organizations fulfilling similar specialized functions. Thus, there are several churches in society and all affirming to be the owners of the "true" salvific message, both for what it is and what is still to come.

The religious competition is the main reason to the dynamic approximation between religious social and social interests.

With the secularization of the State and the end of monopoly as well as state guarantee of religious freedom and tolerance, the number of religious agents and groups and the diversification of the religious products and services have increased. In this pluralist context, the religious associations, to survive and grow, are compelled to compete, dispute market. For this purpose, many religious organizations, besides reinforcing their proselytism, stimulating the clergy activism and the lay militancy, try, as a form of attracting the customers and recruiting new adepts, to conquer new niche markets, specializing in the offer of products and services which are adapted to specific interests and preferences of certain social strata [34]

The pluralist context, result of secularization, increases the possibility of different social interests from the most distinct groups to be meet by specialized religious organization. The interest of being blessed in order to "live well and long on the Earth", for instance is more likely to be pursued by individuals of different social classes. However, the meaning of living "well" varies according with several aspects, including social condition, and even, assuming an anti-religious character. For one living "well" is related to basic questions as paying his bills at the end of the month, for the other, it means having more free time with the family. Therefore, in a society that shows wide offers of religious organizations, the individuals are supposed to look for an organization that best reconciles their interest with the institution's teachings, doctrine and exemplar conduct.

Hence, the religious organization should bring the specialist's prophecy closer to the churchgoers' interests. In a plural religious field, if the individual does not find in the religious organization the satisfaction of his interests, he may easily satisfy them in other denomination.

The second variable to be analyzed comes from the following principle: a religious organization which, in this competitive and pluralist context that characterize religious modernity, fulfills the mission of "connecting" Man to God needs to bear the various economic costs - from the specialist's salary, the employees' salary, purchasing and maintenance of electronics, to the regular bills, such as water and light. The necessity of bearing the costs is not its specialized function; nevertheless, the "good management" of religious organizations becomes essential to their own success. Dutra and Macedo [35] state that "'good management' is the one which best complies the function of coordinating the kind of work related to reproducing the predominant functional reference in this organization". Therefore, the full compliance of the specialized function demands the full compliance of secondary functions by the religious organization.

Among the critics of religious organizations that are neo-pentecostal, a recurrent one is the focus of these organizations in generating profit [36]. An important pastor from this neo-pentecostal movement in Brazil went on to assert that "religious services which are not profitable" should cease to happen. If the economic criteria becomes the most important to the coordination of the organization, the "good management" oriented by the religious function is compromised. On the other hand, the necessity of economic survival of the organization becomes evident, 
since, in a modern society, religious organizations need to bear their costs just as the other organizations. Thus, the religious organization has as a non-specialized function the economic coordination.

Mariano affirms that the consolidation of the modern pluralist situation influences decisively the religious organization. The market logic orients the organizational actions, specially the religious proselytism. The Pentecostal organizations have prioritized an organizational model and denominational management of business model, which accents even more the "concentration and verticalization of the ecclesiastic power and the administrative and financial centralization" [37].

Finally, the relation between religious organization with the specialist (and with the church auxiliaries) Abrutyn observes that the "entrepreneurs are responsible sculpt the institutional spheres, producing and distributing cultural goods and views of reality, and, even more important, protecting their central integrity. This responsibility also becomes the religious entrepreneur, i.e., the religious specialist.

Entrepreneurs innovate symbolically, normatively, and organizationally (Abrutyn and Van Ness 2014) and, when "successful," can generate powerful collective emotions [...] that attach members to each other, the group, and a larger, substantive institutional sphere (Lawler et al. 2009), and also create powerful commitment and, sometimes, merger to the social and role identity associated with these attachments [38]

However, the process of functional secularization and differentiation presents a risk to the religious specialist, since besides the necessity of economic survival the specialist must deal with religious competition. The religious specialists and organizations are intimately connected through the process of secularization and functional differentiation. The religious organization ensures, up to appoint, some structural and symbolical independence to the religious specialist, allowing him to reconfigure and adapt his message and doctrine to the group's demands. In other words, the relation between the specialist and the organization guarantees the existence and reproduction of the religious prophecy in society. Despite not being the only component of the religious system, the religious organization is decisive to the survival and importance of the religious sphere in the secularized society.

On the other hand, religious organization requires from the religious specialist an answer to demands and desires of his members [39]. As previously mentioned, if the organization components do not see in this specialist the capacity to satisfy their demands, they will find another to do so.

But regardless of the variety of personal styles, the teachings of a religious, charismatic leader must deal with the ultimate concerns of a group of people.
Clifford Geertz (1966) states that meaning, morality, and suffering are three points where chaos threatens to break upon man, and any religion which hopes to persist must cope with these problems. Likewise, any religious, charismatic leaders who wish to maintain their authority over a following must also espouse an ideology to cope with these three basic points where chaos threatens to impinge on the consciousness of $\operatorname{man}[40]$.

Furthermore, the organization needs to coordinate the relation between the specialist and the other employees, i.e., coordinate the structure of careers in the religious organizations. According to the Weberian predictions, the bureaucratic management, based on the impersonal coordination, would be the rule manifested in the social spheres. Even though the bureaucratic management interferes in the religious organization, the charismatic intra-organizational domination corresponds to the main decision form, in other words, the authority to ordain church workers, pastors, missionaries etc. falls on the religious specialist. In short: the specialist usually concentrates great power of decisions on "admissions", "promotions" and "firements".

The specialist's authority of Pentecostal churches may be exemplified by Simonton Araújo's words - pastor of "Missão Evangélica", the largest neo-pentecostal church in Vila Velha, Espírito Santo:

I am the owner of the vision. I received the vision from God of how church should be and in this lays my authority. Nobody else in here has more authority than me on making decisions or choosing pastors. That's why I do not open congregations or missionary points. If someone comes here and asks me to use the name "Missão Evangélica", I'll give my blessings, but I won't be the pastor of his church. That is the vision God gave him. I have to respect the vision God gave me and do as much as possible to make it successful [41].

In Pentecostal churches, the rule of employee's remuneration is: only the main religious specialist receives a financial remuneration, which can be altered with the organizational membership growth. The neo-pentecostalism popularized a centralized form of religious organization, non-common to the classic Pentecostalism and the deuteron-pentecostalism. Not only are "filial" churches linked to a "matrix" religious organization, but directly to the religious specialist who founded that organization. Subsequently, Edir Macedo is bishop of every UCKG, as Valdemiro Santiago has the authority to demand whatever is in any and every World Church of the Power of God. However, for the impossibility of pastoring all the churches, each one has a responsible pastor, who is paid. The remuneration is fixed up to a level of stablished collection; in case the pastor receives more than stablished, he additionally receives part 
of this collection. All of the other church workers and auxiliaries work voluntarily.

The neo-pentecostal churches work with the cellular model, in the Semear church, for instance, which will be analyzed in this paper, it is rare the opening to "filial" churches, once the cell become "branches" of the churches in different places. Thus, the main religious specialist of the organization is responsible to consecrating pastors, church workers, cell leaders and worship ministers. All of these but the "owner of the vision" voluntarily work and their growth in the organization is totally dependent of the main religious specialist's approval.

Considering these three variables, we may see the religious organization privileges religious objectives, but should be oriented by other considerations, which are mentioned in this work: 1) external competition with other organizations, 2) economic survival of the organization, 3) structuring of careers. We therefore will analyze three religious organizations under the influence of neo-pepentecostalism.

In order to analyze how Pentecostalism influences the religious organizations, demonstrating how the "Pentecostal trident" is adapted to different religious demands becomes essential. What each individual expects from his relation with the transcendent is directly related to his desires and necessities; in other words, the social interests of this individual are expressed in affinity with his religious interests.

The "Pentecostal trident" is a new form of religious understanding produced by neo-pentecostalism and impacts the Brazilian religious field. Observing the "Pentecostal trident" in these different organizations we may evaluate how Pentecostalism is adapted to different social interests.

Three religious organizations and the impact of neo-pentecostalism are analyzed in this paper. The World Church of the Power of God emerges due to this phenomenon, the Semear church is transformed in a new organization due to its effects and the Baptist church is modified both liturgically and structurally due to the neo-pentecostal strength.

In this organizational context, the Theology of Prosperity, first component of the "Pentecostal trident", acts as the speech of "magical domination" of the world. With the magic action of God in the world, which can be accessed through positive thinking and the purchase of sanctified objects, the believers have the possibility to improve life in several aspects, either through access to the worldly pleasures, the new job opportunities or even the cure to any disease. This does not result, however, in a unidimensional economic use of the prosperity idea, since other spheres and dimensions, such as affective life and mental health, are also part of the practical understanding about what constitutes a prosperous life. In spite of the increase in purchasing power and the multiplication of assets constantly being associated to the theology of prosperity, there are other forms of expression.

In the three organizations, the theology of prosperity may be seen in diverse arrangements. In churches that emphasize "magical interests", as the World Church of the Power of God, prosperity is focused on the economic sphere and, specifically, on the satisfaction of urgent material needs, but includes other spheres, such as family, specially solution of conflicts and dramas that threaten disintegrating domestic unit. The biblical texts which are mentioned usually refer to the divine action fulfilling needs. Being prosperous is related to having basic needs fulfilled by the transcendent. Despite the importance of the earthly prophet, divine action is related to individual faith. The Pentecostal mage has responsibility to impair evil deeds, prepare the ground to divine action; it is up to the individual the use of faith to receive divine grace. Prosperity is not linked to the absence of misfortunes, but the capacity to promptly solve them - a headache that stops you from working or an addicted son.

While religious organizations like World Church of the Power of God give the theology of prosperity emphasize the immediate, organizations like Semear church, which seek for building a new sense for the world, see "prosperity" as the divine promise of a new position in the world. What is in play is a better future than the present. Through the messages, cells and meetings the theology of prosperity diffusion generates dispositions for a world that is understood as belonging to the believers. To sum up, the theology of prosperity in organizations like Semear church, which preach the entrance in a world that did not belong to them so far, may be observed in two aspects: 1) right administration and investment of the goods these individuals own and 2) construction of an intra-organizational social capital which allows the formation of a network, facilitating the exchange of goods and services among the organization members. Prosperity, in this case, is linked to the economic sphere, but it also other spheres such as family. As the leader of Semear church, Apostol Luciano stated:

Prosperity is, firstly, result of faithfulness to God, life with God. The Bible teaches it is faith, I won't try to explain it, because there is no explanation, you believe it or not. So, God honors who is faithful to Him. This is the spiritual part of Prosperity, which is more important than the material. The Bible says everything a man sows, he will reap. When the person becomes faithful, God, somehow, will bless him, He will make things happen. This is the spiritual. Now, the social, we have to understand that when this person arrived in church, he spent his money with booze and he won't anymore, with cigarettes and she doesn't anymore, he went out for parties and nightclubs and won't do this anymore. Now, this person is all about family. This is the social part. As for the direct financial material, I teach my church and my people to manage it. [42] 
In organizations such as the Second Baptist Church in Campos, in other words, religious organizations which are directly connected to the Mission Pentecostalism, but receive influence of the Pentecostalism in the last decades, Theology of prosperity is also perceptible. However, the emphasis may not be found in the financial enrichment, as in the organizations that focus on magical interests, nor in the management of acquired goods. Mission Protestant churches are based on historical doctrines. The Baptist church, for instance, has a basic quadrilateral: repentance, faith, water baptism and communion. The relation with the "world" was, historically, a question diverse theology tried to solve. As result, the theodicy of suffering was integrating part of the Mission churches preaching. The theology of prosperity has grown on the Mission Protestantism once it proposes a new form of relationship with the world, i.e., victory over it in the present. The Mission Pentecostalism theologies affirm "the world lays on the evil", but the repentance action and the individual's faith may guarantee salvation and the certain of a better yet to come world. The theology of prosperity substituted the salvific and the imminent messianic return messages for the message of welfare in this world - either material, immaterial or social welfare.

The success of the theology of prosperity is linked to the success in the spiritual war in the Pentecostal message. Where there is an enemy which does not desire the victory of the saints, prosperous life demonstrates exactly victory over this enemy. That is how, in theology of prosperity, the spiritual war adapts according with the magical and religious interests of different religious organizations.

In religious organizations which focus on magical interests, the spiritual war happens at all times, affecting all the areas of the individual's life. "Everything that is bad in this world originates in Satan and his demons. They cause all the misfortunes which directly or indirectly affect men" [43]. Thus, the solution for the evils and problems is only one: defeating the devil. This is the answer for curing diseases, getting jobs, acquiring goods and saving children from drugs. Combating the devil with prayers, pastors' intercession and the use of sanctified goods are the leadership. The spiritual battle happens in real and present form during the meetings. In one of the intercession meetings which I attended, one of the church workers stated: "My God, an angel and a demon are fighting in here". Suddenly, he took an imaginary arrow from his imaginary quiver from his back and started shooting arrows in the demon that fought the angel. The spiritual war is as real and present as food, clothes and money. The devil's presence is to be combated and watched.

In religious organizations in which neo-pentecostalism acts in the formation of the future, the devil is also integrant part of preaching and important for the success of the organization. Differently from the daily spiritual battle during the services, spiritual war happens every day as a form of temptation and obedience proof. Personal and social success - preached by churches, such as Semear - is based on "biblical values", i.e., biblical infallibility, tenth faithfulness and family and hierarch respect.

The bible won't change because of modernity. It includes family principles, such as covenant, commitment between a man and a woman till death do them part. So, the church's role is to rescue the lost values, and maintain its values. I think the greatest challenge is not negotiating biblical principles regarding any kind of social value, not only family, friendship and commitment.

The devil attempts individuals to break the "values and principles", deviating from the happiness and prosperity "path". The devil acts in the world and the individuals lives hardening obedience and suggesting "shortcut" to obtain pleasures and desires. In other words, the devil intends to stop "God's plan for people's lives" from coming true, but his actions happen in a more abstract realm (the "values and principles").

In religious organizations with historical formation, the devil was a secondary image and acting in the shadows the world lays on evil. The acceptance of Pentecostal logic in the mission protestant churches brought the spiritual war to a new status. The devil ceases to be a transcendent being and becomes acting in a daily basis. Moreover, life after death which should be conquered in this world and fully enjoyed in the world to come may be lived and enjoyed here and now. Fighting the devil, living better and solving crisis - emotional, familiar and material - becomes tangible. "Suffering" is replaced by "welfare".

Finally, besides the theology of prosperity and the spiritual war, the religious organizations analysis demonstrated a flexibilization of habits and customs, considering the religious interest of each organization.

In religious organizations such as the World Church of the Power of God, habits and customs are entirely secondary. During the meetings, no time is available to discuss habits and customs, since it should be invested in preaching the theology of prosperity and spiritual war. During the services, priests mention addictions, for instance, but there is not a direct prohibition or even attitudes which Christians must be known, because such mark is the prosperity, i.e., the divine interference and attention to the individual's requests and satisfaction of his needs. 
Table 1. Pentecostal trident and religious organizations

\begin{tabular}{|c|c|c|c|}
\hline \multicolumn{4}{|c|}{ Pentecostal Trident } \\
\hline & Prosperity Theology & Spiritual War & Habits and Customs \\
\hline $\begin{array}{l}\text { World Church of the Power } \\
\text { of God }\end{array}$ & Solution for urgent questions & $\begin{array}{l}\text { Present in all areas of the } \\
\text { individual's life }\end{array}$ & Not emphasized \\
\hline Semear & $\begin{array}{l}\text { Construction of a better life in the present } \\
\text { and near future }\end{array}$ & Present in the temptations & $\begin{array}{l}\text { Construction of new habits and } \\
\text { customs }\end{array}$ \\
\hline Second Baptist Church & Search for a social welfare & Present in the "evil world" & Utilization of good sense \\
\hline
\end{tabular}

In Religious Organizations as Semear, there is a search for the creation of new habits and customs, which are better related to the life in modern world. Those habits are related to prohibitions in relation to sensuality, dinks, cigarette, songs and movies, i.e., matters related to entertainment sphere. Nevertheless, such prohibitions vanish for matters related to acquisition of material or cultural assets, for example. Thus, a new way to acquire material and cultural assets, and build new social capital is emphasized, prioritizing family and interorganizational relationship.

At last, in protestant organizations, influenced by Pentecostalism, habits and customs are altered so as to be according to new religious interests. The Second Baptist Church, for instance, condemns "vanity"

Christians are free to adorn themselves, as long as they have "modesty" in mind. They must know that they are different, that they must be holy. If what they wear cause them to be reason for scandal or discredit to their spiritual life, they make a serious mistake. Glorifying God with their body is the basic criteria for Christian behavior.

On the other hand, these organizations allow their members to consume alcoholic beverages, attend non-Christian concerts, watch R-rated movies, and play war games on videogame. "Good judgement" must be the guide of their actions.

Analyzing the stories and reunion previously described, we are able to observe how the "Pentecostal Trident" is adapted to the needs of different social groups, represented in distinct religious organizations [46].

The chart above helps us realize that Pentecostalism brings a new logic of relationship with society, and such logic is adapted according to different religious interests related with distinct social interests.

Therefore, it is possible to perceive that religious messages and doctrines preached by the religious specialists and spread by the religious organizations 1) are not exempt from the social interests of the individuals who compose them; 2) cannot ignore the existence of a secularized society which dictates the rules of participation that need to be obeyed and 3) need to differentiate from others in order to reach success on religious field, customizing their practices and services to particular audiences [47].

\section{Conclusions}

Labeling the religious phenomenon as anti-ethic to modernity is a mistake that sociology and social sciences in general still make. Nonetheless, the importance of religious sphere in the conduct and trajectories of individuals lives, including public space, does not allow us to talk about a process of religion decadency or its withdraw from public sphere. Theories of Secularization, which understood the concept as associated with the process of decadency and privatization of religion, need to reevaluate and reformulate their idea of secular society, taking into consideration simultaneous tendencies of weakening and strengthening of public and private importance of religion. Luhmann's theory of society provides a concept of secularization that considers these simultaneously opposed tendencies within a same society. Modernity may be antireligious on its political, scientific or artistic spheres, but it is also religious on the specific sphere that encodes communication through the transcendent/immanent difference and organizes beliefs and practices based on specific programs about the relationship between both binary poles.

In Modernity, the transcendent/immanent code is no longer a "supercode", a superdifference, i.e., this code does not organize the worldview and world construction in all social spheres any longer. Whereas specific binary difference of religion, we may differentiate, on a daily basis, one from other binary difference, as having/not having, ruler/ruled, licit/illicit, sick/healthy. The functional differentiation of society may be synthetically characterized as a social practice frequently institutionalized to differentiate differences, i.e., to differentiate between binary codes useful as specific references to the construction of worlds and social practices differentiated among themselves. Functional differentiation, while defining form of modern society and the relationship among religion and other social spheres, must be the starting point to the analysis of religious organizations. Therefore, the secular condition consists in the fact of any and every religious practice or organization is inserted in a society also formed by binary non-religious differences, i.e., in the fact that the construction and access to the world does not occur by the religious social system alone. 
The multiplicity of functional orientations, caused by the non-convergence between the binary perspectives and differences of the distinct functional subsystems, serves as a source of questions to empirical analysis about religious organizations in modernity. The argument is illustrated by the historical formation of religious organizations which we studied empirically on the development of the Brazilian religious field, emphasizing the following aspects: 1) Economical survival of the organization; 2) Structure of Internal careers; 3) External competition with other organizations.

Modernity demanded from religion new ways of competition and new strategies so as to influence society. Thus, a set of new practices, semantics and organizations comes through in order to answer to demands of this new age. Said set is Pentecostalism. According to Arenari [48], Pentecostalism is the main responsible for the changes on Brazilian religious field and the main responsible for the political, cultural and social impact caused by religion on Brazilian society in the last decades. To demonstrate Pentecostalism's impact on modern religious organizations, we have introduced the "Pentecostal Trident", i.e., Theology of Prosperity, Spiritual Wat and Flexibilization of Habits and Customs [49].

Table 2. Pentecostal Triple and Emphasized Importance

\begin{tabular}{|c|c|}
\hline Pentecostal Trident & Importance \\
\hline $\begin{array}{l}\text { Theology of } \\
\text { Prosperity }\end{array}$ & $\begin{array}{l}\text { Utilization of "divine" to acquiring social } \\
\text { success }\end{array}$ \\
\hline Spiritual War & $\begin{array}{l}\text { The devil as representation of the evil in the } \\
\text { world. Empowerment of the individual as an } \\
\text { example of success }\end{array}$ \\
\hline $\begin{array}{l}\text { Flexibilization of } \\
\text { Habits and Customs }\end{array}$ & $\begin{array}{l}\text { Inclusion in society. Allows the individual to } \\
\text { accept the world benefits and to adapt to the } \\
\text { social spheres. }\end{array}$ \\
\hline
\end{tabular}

Theology of Prosperity is a way of understanding the divine which emphasizes the use of God's power to "conquer the world" [50]. However, it does not result in a unidimensional use of the economic idea of prosperity, as other spheres, e.g., emotional life and mental health, are also part of the practical understanding of the constitution of a prosperous life. Even though the increase of purchase power is in constant use and constantly propagated by Neo-pentecostalism, this is not the only way by which Theology of Prosperity is put into practice. What matters is the capability to utilize "supernatural resources" to reach what is believed to be a "good life".

Spiritual War is also an important element to the accomplishment of prosperity in the individual's life, because the individual who is socially oppressed is, by the power of God, empowered to humiliate the "owner of this world". Following this logic, there is no one more powerful than this individual who was once oppressed. The "whole world lieth in wickedness", the Devil is the "prince of this world", but no even said prince is able to overcome the power of Pentecostal believer. Therefore, not one else is, not even those who socially oppress these believers.
Besides, Flexibilization of Habits and Customs may be understood as directly associated to Theology of Prosperity and Spiritual War, once it allows the individual to enjoy the benefits of the world. Religion depends on this important doctrine to accept the world other than reject it.

Therefore, the analysis of these three constitutive elements of $(\mathrm{Neo})$ Pentecostal organizations or organizations influenced by Pentecostalism may combine concepts of theory of systems - as the theory of functional differentiation and the systemic sociology of organizations - with approaches about social stratification as important factor in the constitution of "specific niches of religious market" (Weber and Bourdieu). The concepts of system theory allow us to observe how religious organizations develop and adopt these Pentecostal elements in an environment made up by a variety of functional systems and binary differences. On the other hand, approaches about social stratification permit us to observe how religious organizations customize their offer according to social and religious interest differences that characterize and define their believer audience or potential believers.

\section{REFERENCES}

[1] GEYER, C.-F. (1982). "Das Jahrhundert der Theodizee“.Kant-Studien, 1-4: p. 393-405.

[2] SCHNEIDER, W. L. (2011). "Religion und funktionale Differenzierung". In: SCHWINN, T. et al. (eds.). Soziale Differenzierung. Handlungstheoretische Zugänge in der Diskussion. Wiesbaden: VS Verlag.

[3] LUHMANN, N. (1977). Funktion der Religion. Frankfurt a.M.: Suhrkamp. 301,302

[4] WOHLRAB-SAHR, M./BURCHARDT, M. (2012). "Multiple secularities: toward a cultural sociology of secular modernities". Comparative Sociology, 11: p. 875-909.

[5] EISENSTADT, S. N. (2000). Die Vielfalt der Moderne. Weilerswist: Velbrück Wissenschaft.

[6] PARSONS, T. (1974). O sistema das sociedadesmodernas. São Paulo: Pioneira.

[7] PIERUCCI, A. F. (2008). "De olhonamodernidadereligiosa". Tempo Social, 2, p.9-16.

[8] LUHMANN, N. (1977). Funktion der Religion. Frankfurt a.M.: Suhrkamp. 301,302

[9] SCHNEIDER, W. L. (2011). "Religion und funktionale Differenzierung". In: SCHWINN, T. et al. (eds.). Soziale Differenzierung. Handlungstheoretische Zugänge in der Diskussion. Wiesbaden: VS Verlag.; 190-199

[10] LUHMANN, N. (1996). Liebe as Passion. Zur Codierung von Intimität. Frankfurt a.M.: Suhrkamp; 284

[11] LUHMANN, N. (1996). Liebe as Passion. Zur Codierung von Intimität. Frankfurt a.M.: Suhrkamp; 218 
[12] LUHMANN, N. (1977). Funktion der Religion. Frankfurt a.M.: Suhrkamp. 289

[13] LUHMANN, N. (1977). Funktion der Religion. Frankfurt a.M.: Suhrkamp. 293

[14] LUHMANN, N. (1996). Liebe as Passion. Zur Codierung von Intimität. Frankfurt a.M.: Suhrkamp; 296

[15] LUHMANN, N. (1996). Liebe as Passion. Zur Codierung von Intimität. Frankfurt a.M.: Suhrkamp; 295

[16] LUHMANN, N. (1996). Liebe as Passion. Zur Codierung von Intimität. Frankfurt a.M.: Suhrkamp., 394

[17] WOHLRAB-SAHR, M./BURCHARDT, M. (2012). "Multiple secularities: toward a cultural sociology of secular modernities". Comparative Sociology, 11: p. 877.

[18] WOHLRAB-SAHR, M./BURCHARDT, M. (2012). "Multiple secularities: toward a cultural sociology of secular modernities". Comparative Sociology, 11: p. 382.

[19] BAYLY, C. A. (2004). The Birth of the Modern World 1780-1914: Global Connections and Comparisons. Oxford: Blackwell Publishing.

[20] PETZKE, M. (2013). Weltbekehrungen: ZurKonstruktionglobaler Religion impfingstliche-evangelikalenBewegung. Bielefeld: Transcript Verlag; p. 14

[21] PETZKE, M. (2013). Weltbekehrungen: ZurKonstruktionglobaler Religion impfingstliche-evangelikalenBewegung. Bielefeld: Transcript Verlag; 18

[22] PETZKE, M./TYRELL, H. (2012). "Religiöse Organisationen". In: APELT, M./TACKE, V. (eds.). Handbuch Organisationstypen. Wiesbaden: Springer VS

[23] CHANG, P. M. Y. (2003). "Escaping the Procrustean Bed. A Critical Study of Religious Organizations, 1930-2001". In: DILLON, M. (ed.). Handbook of the Study of the Sociology of Religion. Cambridge: Cambridge University Press; 128

[24] WEBER, M. (1982). Ensaios de Sociologia. Rio de Janeiro: LTC editora S.A; 310

[25] WEBER, M. (2000, 2009) Economia e Sociedade: fundamentos da sociologiacompreensiva. Trad. De Regis Barbosa e Karen Elsabe Barbosa; ver. Téc. de Gabriel Cohn, $4^{\text {a }}$ ed. - Brasília: EditoraUniversidade de Brasília (reimpressão).

[26] BOURDIEU, P. (2003). Aeconomia das trocassimbólicas. São Paulo: Ed. Perspectiva.

[27] LUHMANN, N. (1996). Liebe as Passion. Zur Codierung von Intimität. Frankfurt a.M.: Suhrkamp

[28] ABRUTYN, S. (2014). Religious Autonomy and Religious Entrepreneurship: an evolutionary-institutionalist's take on the Axial Age. Koninklijke Brill: Leiden.

[29] BURITY， J. (2015). “A Cena da ReligiãoPública: Contingência, Dispersão e DinâmicaRelacional. Novos Estudos 102, p.93 - 109.

[30] MACHADO, M. D. C. (2015). "Religião e Política no BrasilContemporâneo: umaanálise dos Pentecostais e
CarismáticosCatólicos". Religião e Sociedade, 35, 2, p. 45-72.

[31] ARENARI, Brand. Religiosidade Popular e Política: o movimento neopentecostal como caso ilustrativo dos limites do aprendizado político no Brasil". Revista Temáticas. Campinas, 2006

[32] ORO, A. P. (2003). "A Política da Igreja Universal e seusReflexosnos Campos Religioso e PolíticoBrasileiros". Revista Brasileira de Ciências Sociais, 18, 53. p. 54-69.

[33] DUTRA, R. (2016). “A Universalidade da Condição Secular”.Religião e Sociedade, 36, 1, p. 151-174.

[34] MARIANO, R. (2003). "Efeitos da Secularização do Estado, do pluralismo e do mercadoreligiosossobre as igrejaspentecostais". Civitas - Revista de Ciências Sociais, 3 , 1, p. 114

[35] MACEDO, E. (1987). Orixás, Caboclos e Guias: DeusesouDemônios? Rio de Janeiro: Universal Produções; p. 12

[36] ARENARI, Brand. Pentecostalism as religion of the perifety: an analysis of the Brazilian case. Tese de Doutorado, 2013.

[37] MARIANO, R. (2003). "Efeitos da Secularização do Estado, do pluralismo e do mercadoreligiosossobre as igrejaspentecostais". Civitas - Revista de Ciências Sociais, 3,1. P.5

[38] ABRUTYN, S. (2014). Religious Autonomy and Religious Entrepreneurship: an evolutionary-institutionalist's take on the Axial Age. Koninklijke Brill: Leiden. P.11

[39] BOECHAT, João. Religião e Classe Social: uma análise dos especialistas religiosos de diferentes segmentos evangélicos sob a influência do Pentecostalismo. Dissertação de Mestrado em Sociologia Politica, 2017.

[40] BARNES, D. F. (1978). "Charisma and Religious Leadership: An Historical Analysis." Journal for the Scientific Study of Religion 17, p. 3

[41] Interview given to me on 10/15/2015

[42] Interview given to me on $08 / 02 / 2015$

[43] MACEDO, E. (1987). Orixás, Caboclos e Guias: DeusesouDemônios? Rio de Janeiro: Universal Produções; p.103

[44] Interview given to me on 08/02/2015

[45] Interview given to me on 11/05/2015

[46] BOECHAT, João. Religião e Classe Social: uma análise dos especialistas religiosos de diferentes segmentos evangélicos sob a influência do Pentecostalismo. Dissertação de Mestrado em Sociologia Politica, 2017.

[47] BOECHAT, João. Religião e Classe Social: uma análise dos especialistas religiosos de diferentes segmentos evangélicos sob a influência do Pentecostalismo. Dissertação de Mestrado em Sociologia Politica, 2017.

[48] ARENARI, Brand. Indústria Cultural e religiosidade mágica: o racionalismo adaptativo do Neopentecostalismo. ANPOCS, 2007

[49] BOECHAT, João. Religião e Classe Social: uma análise dos 
A Theoretical Analysis Based on Pentecostalism in Brazil

especialistas religiosos de diferentes segmentos evangélicos sob a influência do Pentecostalismo.

Dissertação de Mestrado em Sociologia Politica, 2017.
[50] ARENARI, Brand. Pentecostalism as religion of the perifety: an analysis of the Brazilian case. Tese de Doutorado, 2013. 